\title{
Ubuntu leadership in conversation with servant leadership in the Anglican Church: A case of Kunonga
}

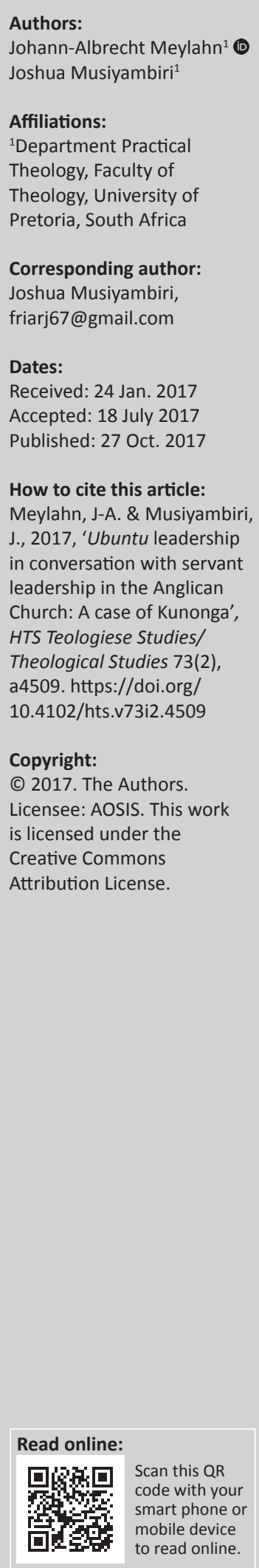

This article is a practical theological reflection on leadership practice. The study offers a critical reflection of the Church's practice of leadership as it interacts with the practices of the world. The leadership has been focused upon conversation between $u b u n t u$ and servant leadership as presented by their respective theorists. The two concepts ubuntu and servanthood are congruent to each other, and both have been used in connection with leadership studies, offering leadership a set of values. The key underlying principle is a focus on the importance of service and community. These leadership concepts have been applied upon the Anglican Diocese of Harare in a recent empirical study which revealed that, by and large, the institution does not embrace $u b u n t u$ and servant leadership.

\section{Introduction to ubuntu leadership}

Samkange (1980:45) and Tutu and Allen (2011:22) identify ubuntu as an Afrocentric philosophy that provides moral guiding principles in leadership. Chikanda cited in Prinsloo (1998) coins ubuntu as an 'African Humanism that involves alms-giving, sympathy, care, sensitivity to the needs of others, respect, consideration, patience and kindness' (p. 41). Similarly, Broodryk (2006) cited in Msila (2008:1110) posits that ubuntu contains values of humaneness, caring, sharing, respect and compassion as well as warmth, empathy, giving, commitment and love. Also, Mangaliso (2001) defines ubuntu as:

Humaneness - a pervasive spirit of caring and community, harmony, and hospitality, respect, and responsiveness that individuals and groups display for one another. Ubuntu is the foundation for the basic values that manifest themselves in the ways African people think and behave towards each other and everyone else they encounter. (p. 24)

The above definitions locate ubuntu as an Afro-based philosophy that fosters communal approach to handling tasks at hand. The application of ubuntu philosophy requires strong community linkages and interdependence, democracy, transparence, responsibility and accountability. The leader's role in an ubuntu-based context is expected to reflect the abovementioned qualities, which is a high state of social responsibility. Such a societal role might be what Magesa (2003) argues, when he writes of 'maintenance of strong relationships is the central moral and ethical imperative in African communities' (p. 124). Msila (2008:70) argues that the concept of ubuntu is crucial in a variety of institutions as it helps in developing practices of doing things together. Furthermore, Mangaliso (2001:32) argues that incorporating ubuntu principles in management holds the promise of superior approaches to managing organisations.

A salient feature of chieftainship ${ }^{1}$ that is directed by the spirit of $u b u n t u$ was that councils and courts augmented the mambo chief or king's authority. The members of these councils were expected to have some wisdom and filled with ubuntu to be able to help with regulating daily concerns of the chiefdom. This would be what Ogot (1953) meant when he writes:

However, this same system, which safeguarded the office of chieftainship also provided the necessary checks and balances to the power of the chief. He was bound in this commonwealth inhabited by gods, spirits, and men, by customs and traditions; and also, the chief depended on important decisions, on the will of the elders, for this was government by discussion. (p. 26)

1.Chieftainship is a colonial notion used by white settlers to control African governance, hence it lacked in totally embracing the philosophy of ubuntu. See A.K.H. Weinrich, Chiefs and Councils in Rhodesia; Transition from Patrichal to Bureaucratic Power, Heinmann, London, 1971, p. 11. Bishi argues that institution of traditional leadership evolved through the pre-colonial, colonial and post-colonial period. He argues that it is a political position in which indigenous leaders where bestored with authority. Even though it has been wrapped into the western aristocratic rule, the traditional head, Mambo is expected to safe-guard traditional values in which I argue that such values include ubuntu. For Bishi, see G.Bishi, 'The Colonial Achive and Contemporary Chieftainship Claims: The Case of Zimbabwe, 1935 to 2014,' University of Free State. 
The issue of traditional leadership is in layers. I consider Ogot's point allude to the nominal roles and expectations of the mambo as a leader who held the community at heart and was in respect of the advice from the sadunhus around him. The traditional checks and balances helped to sanction a wayward chief in case of there being any anti-social governance. Involvement of other people in decision-making may be best captured by a Shona saying: 'Ishe vanhu' (there cannot be a king without community support). The African traditional governance guided by ubuntu was, therefore, democratic as it included several elders in making decisions (Chimuka 2013:69).

However, most African leadership has lost the ubuntu philosophy. As Obiakor (2004:405) argues, African leaders misinterpreted the concept of western leadership, tallying it to amassing of wealth by the leader. Nthamburi (2003:153) also notes that African leaders surround themselves with relatives because of nepotism rather than merit, thereby compromising the quality of service rendered because some of the incumbents would lack the good working skills. The good values enshrined in ubuntu have been shattered and lost by leaders' failure to accommodate objective principles that advance transparency, trustworthiness and democracy. Furthermore, Ebegbulem (2012:221) expresses that leadership in Africa has lost values of ubuntu and been dominated by a self-serving dictatorship which has developed injustice, violence, corruption and dwindling economy. The communal approach of the ubuntu philosophy is like one of servant leadership qualities of having the others at heart, thereby ensuring that the needs of others are first met.

In the next section, I will introduce servant leadership and thereafter analyse how the two views were tested upon the leadership of the Anglican Diocese of Harare.

\section{Servant leadership}

Block (2011) notes that the question that servant leadership raises is 'what does it require to make a real difference in the world?' (p. xiv). The question suggests a need for a change within the would-be servant leader, to bring a difference in the way of approaching challenges. There is in that person a desire to resolve the way of handling challenges in a different manner. Change, however, is not easy but requires determination. Block (2011) further notes that the heart of transformation is not in the vision statement but the way it is embodied' (p. xv). Spears (1998:5) identifies some key qualities of servant leadership as listening, empathy, healing, awareness, persuasion, conceptualisation, foresight, stewardship, commitment to the growth of people and building community. The list is not exhaustive.

Smith (2005:3) argues that Robert Greenleaf, the originator of the term servant leader, used seemingly contradictory words: servant and leader with the intention to emphasise a new thinking about leadership. Embedded within the paradox of servant leadership is a transformation of the view of leadership to that which leads by willingly doing the menial work. Ferch and Spears (2011) posit that Greenleaf seems to ask, 'What leadership can you offer as a servant? Not what service can you render as a leader?' (p. xii). The delivery of service becomes the centre of focus rather than the leader. The leader's primary motivation is in enhancing greatness in others. So according to Smith interpreting Greenleaf, legitimate leadership would not come by the exercise of power, instead of by a fundamental desire to serve others (Spears 1998:xii). What is critical in servant leadership is the desire to serve before leading ensuring that other people's highest priority needs are being served (Baggett 1997:31; Block 1993:23; Covey 2006 1990:5; Greenleaf \& Spears 1977:12 13; Kouzes \& Posner 1995:95). As long as power dominates the mind about leadership, we cannot move to a higher standard of leadership. Service should be placed at the centre. Russell and Stone (2002:4) argue that even though power is necessary for leadership, its legitimate use is one: service.

Servant leadership model could be one of the models that can resolve the world's leadership challenges if people's attitudes towards service change: having a will to contribute towards a positive change. Let us consider what the servant leadership is. According to Spears (1996), servant leadership is concerned about the social responsibility of the leader to the followers. Spears further argues that servant leadership is:

a model which puts serving others as the number one priority, while generally placing emphasis on four areas: a) Increased service to others, b) A holistic approach to work, c) Promoting a sense of community and finally, d) The sharing of power in decision making. (p. 33)

Vaill in Ferch and Spears (2011) notes five critical areas in Greenleaf's talk about servant leader: (1) the grammar of the phrase itself, (2) Greenleaf's commitment to practice, (3) the importance of mission, (4) the nature and role of persuasion and (5) his ideas about a theology of institutions (p. xi).

Greenleaf and Spears (1998:43) argues that if servant leadership is employed, the persons being served would grow, become healthier, wiser, freer, more autonomous and more likely to become servants themselves. He further argues that the servant leader should enjoy a mutual relationship with followers. Greenleaf refers to seekers, those critically concerned about the direction of leadership, as a vital component of a community. The leader should ensure that the seekers are adequately nurtured. Seekers add value to the leadership because they bring openness, aggressive searching and good critical judgement (p. 120). He goes on noting that a servant leader adds persuasion backed by persistence, determination and courage to virtue and risk as qualities that strengthen the organisation. As institutions are reconstructed to be serving, there should be the engagement of 'evolution than revolution, persuasion than coercion and manipulation, and gradual than precipitous change' (p. 122). Ferch and Spears (2011) also argue that servant leadership is a long-term transformational approach to life and work inculcating a sense of community and shared power in decision-making (p. 8).

Greenleaf asserts that institutions would function better when an idea takes the lead, not the ' $I$ ' ultimate leader. The 'I am' should be a servant to the idea as well as everyone else involved in the organisation (Spears 1998:78). He further 
notes that a number of organisations lack a shared dream that motivates people to contribute to their potential; hence, they fall into a leadership crisis. Closely related to a shared vision is the idea of freedom within participants. Spears (1998) also argues that freedom contributes to constructive ideas that guide in decision-making. Poor performance by organisations such as hospitals, governments or churches can be attributed to low-grade top leadership without knowledge or care and above all, abusing and misusing power (p. 82). He further suggests that coercive power increases with the domination of social systems within institutions and may be conducted by highly civilised persons and liable to corrupt use (p. 83). Greenleaf questions the moral obligation of coercive power. He asks whether one who possesses coercive power does not have responsibility for the violence that is unleashed on whoever is deemed as resistant to the said power (p. 84). If Christians are to emulate their master, then their application of power should be different. Hays (1996:90) redefines the nature of power on the value of suffering, Jesus uses authority and power to serve than being served, so authentic power being paradoxically defined in the image of the cross. On the other hand, those who possess power and authority to dominate, oppress and kill others are in fact villains and pawns of forces beyond them. This is the case with Herod (Mk 6:14-29) and Pilate (Mk 15:1-15). Jesus' powerlessness tends to be a display of God's victory and power.

Osmer (2008) notes that, 'servant leadership is that which influences the congregation to change in ways that more fully embody the servanthood of Christ' (p. 192). Mainline churches that are on the verge of death may need to transform, embracing less of power and influence yet gaining biblical authority whose power is the servant Jesus Christ.

A holistic approach to work is deduced from the Greenleaf's notion (1996) that 'work exists for a person, as much as the person exists for the work' (p. 8). Greenleaf also argues that institutions should provide human services. Greenleaf (1970) further, posits that institutions are comprised of the community, that is, individuals and groups neatly co-ordinated by servantoriented leadership (p. 30). Leaders tend to breed after their own kind, servant leaders promote servant-oriented followers by encouraging talents in the followers. Smith (2005:4) argues that a servant leader produces a motivated workforce and hence a powerful organisation. How do leaders manage such seemingly challenging tasks of sharing power? Russell (2001) argues that, 'leaders enable others to act not by hoarding the power they have but by giving it away' (p. 80). The concerns of servant leadership are therefore hinged upon regarding service rendered by a community in a mutual relationship, not monolithic leadership. The sense of community entails great responsibility and involvement by every participant. Also, enhanced by the community is continuity of any vision shared.

I will now go on to ubuntu and servant leadership with respect to leadership in the Anglican Diocese of Harare. Could the embodiment of ubuntu philosophy and servant leadership by the bishops assist in the management of the church institution?

\section{Ubuntu and servant leadership in the Anglican leadership}

Both ubuntu and servant leadership models emphasise an involvement of the community in decision-making, execution of duties and also both models embody democracy and power sharing. However, democracy and power sharing resonate more with secular institutions; in the church this notion is best expressed as synodical resolution, a decision that is reached through a consensus. In Jesus' servant leadership example, authority and power come from an ability to humble oneself and willingly serve others as demonstrated by Jesus who washed his disciples' feet (Jn 13:12-15).

How is servant and ubuntu leadership understood and interpreted by clergy and laity in the Anglican Diocese of Harare? In a recent empirical study on the leadership practices in the Anglican Diocese of Harare, I have deduced that the leadership has been characterised by power and authority rather than following democratic, transparent and community involvement such as in ubuntu and servant leadership (Musiyambiri 2016). The majority of the respondents understood the bishops' leadership as autocratic and dictatorial in some instances. Autocracy refers to a system of governance where power is vested in one person. The governance in the Anglican Church in Zimbabwe and the Province of Central Africa is episcopally led and synodically governed; the bishop oversees the Diocese, an exercise he does in consultation with the various administrative committees such as the Standing Committee, the Senate and the Board of trustees (CPCA 1975 Act 5.1; 8.3; 10.1). Dictatorial leadership refers to exhibition of total power. The respondents also agree that leadership by some of the bishops of Harare is associated with possession of resources and power, contrary to popular view by many scholars such as Osmer (2008:188), Russell (2001:80), Hays (1996:90) and Greenleaf and Spears (1977:13) who agree that power has to be given away not possessed.

The empirical research showed that among the five bishops involved, Kunonga scored least in servant and ubuntu leadership while obtaining high scores in autocracy and dictatorship. This should be so because he dismissed the committees which he was supposed to lease with thereby exposing himself to abuse of power. As attested for by Gunda (2008:407), power has been used to manipulate and coerce worshipers by Kunonga being backed by the government's law enforcement agents, the police. Kunonga was the Anglican bishop of Harare 2001-2007 after which he was excommunicated for contravening the Constitutions and Canons of the Church of the Province of Central Africa by his self-initiated withdrawal from the same Province, as stated by the Right Reverend Albert Chama, Dean of Central Africa in his letter to all clergy and laity of the Diocese of Harare on 7 November 2007. Kunonga, however, resisted the order to relinquish office and claimed authority over all properties in the Anglican Diocese of Harare for about 5 years. Worshippers were denied access to church properties unless they followed 
behind Kunonga as the bishop of Harare regardless of his scandalous schismatic move, as reported by Conger (2010) in the Church of England newspaper. The spirit of servant leadership was compromised as can be deduced from Greenleaf and Spears (1998:43) that servant leadership is about considering the needs of others first and pursuing services that benefit the community. Kunonga has been engaged with grabbing church properties for himself, turning church buildings into lodges and schools. Sims (1997) argues, 'servant leadership never splits the church; but it only exposes the divisions that are already there, opening them to the reconciling work of servanthood' (p. 77). The challenges faced by the Anglican Church in Harare are a pointer to the need for pastoral work to seek ways to heal the prevailing cracks and wounds.

The empirical research (Musiyambiri 2016) in which information was gathered from the Anglican bishops of Harare also revealed that most of the bishops in question have found it difficult to relinquish office when it was time for them to leave the see, an ecclesiastical term for the bishop's office. A servant leader knows how to empower other servants and when it is time to leave the office so that they give an opportunity to other leaders to also exercise their leadership skills. Prosser (2007:45) argues that a servant-leader carefully plans for a smooth transfer of power at that moment when it is time to hand over power. Succession for the office of bishop in Harare, however, has had challenges as the supposedly outgoing bishop wanted to remain a time longer or as for Kunonga, he confiscated the church properties and refused to leave the office. The existence of checks and balances during ubuntu governance as mentioned earlier in this script sheds a ray of hope that the community is involved in decisions even when it is time for the leader to leave office, hence applying it to the church would appropriate the checks and balances upon office bearers.

Ubuntu philosophy can be used to shape management and nurturing process that foresees growth of the church. Ubuntu mode of leadership requires a departure from a hierarchical structure to communal involvement, embracing support in collective solidarity or commonality. The departure in structure might be a call for the church to consider making laity involvement more conspicuous. The laity involvement is done through inclusion in the administrative committees I referred to earlier. Msila (2008:71) points out the role of ubuntu leadership as bringing hope in the midst of confusion and chaotic change, and this can also be applied to the Church in Zimbabwe. It is the role of the church leader in this process to function as a medium of hope and a channel for meaning in the church. Servant leadership has more concern for the follower's mind-set to be willing to serve. The church might make a difference in the way new leaders are groomed. Greenleaf and Spears (1998:120) puts emphasis on taking extra care on seekers; if the church learns to nurture seekers, it has a potential to grow as the seekers bring new experiences and good critical judgement.
Spalthoff (2013:2) argues that the philosophy of ubuntu is all about interconnectedness within a community; no one really lives for himself or herself without reference to another person. While Obiakor (2004:407) stresses relations saying; marital relations involved the community and went through a process that bound the families together. Young people had readily available role models. People used to learn things in a pragmatic way - learning was by practical experience. Communal life required patriotism to transmit the values to the coming generations. No family wanted to embarrass the community. Leadership was to be proudly passed on to the children; the model was living up to expectation. The depiction of a community model might be another way which the church could view its ministry; seeing it as a community of believers who are responsible for preserving values and transmitting such values to future generations. Similarly, servant leadership could offer the church ideas of utilising group dynamics in communities as Spears (1996) notes.

Those who hold onto the ideals of an African view regard life without relationships as impossible. To use Tutu's expression, neighbours complement each other or they see the needs of other people. So being human is to be dependent. Ubuntu differentiates us from items (Tutu \& Allen 2011:23). He continues to argue that the practice of ubuntu calls for compassion and gentleness upon the weak and not taking advantage of them. The gravity of ubuntu weighs deep in people's moral actions, which calls for responsibility towards the other. Extortion, corruption, bribery and other vices defy the positive ethical expectations enshrined in ubuntu. The ubuntu philosophy emphasises communal relationships and achievement is regarded for the common good. Our success is the success for the family - God's family, the human being. This resonates with the biblical view of the church as the Body of Christ (1 Cor 12:27). We are all inter-linked such that the suffering of one member triggers pain over the whole body. The church should be fortified by embracing the philosophy of ubuntu and servant leadership both of which embody compassion and gentleness towards the weak. In doing so, the church answers to its mission as outlined by Swinton and Mowat (2006:6), to proclaim healing to the broken world.

Does ubuntu deprive an individual's credibility or enhance it? Kirk and Bolden (2006) note that:

the basic idea of this value system is that the human being is a community being, who without losing personal identity or morality, finds her or his identity and ways of being, in relationships with others. (p. 14)

An individual is valued for that part he or she plays on behalf of the community. This relationship does not imply that the individual is swallowed up by the community. Also, Louw (2002) argues that $u b u n t u$ is not 'an oppressive collectivism or communalism' (p. 10); on the contrary, Ndaba (1994:14) cited in Kirk and Bolden (2006:14) argues that ubuntu accommodates diversity in the community. Louw (2002) posits that 'Ubuntu dictates; if we [are] to be human, we need 
to recognize the genuine otherness of our fellow citizens' (p. 8). I note that if the church approached their way of life with the ideal sense of ubuntu, everyone would become concerned about the other person as it were unto self. In this regard, when one sins, the community has sinned, when one excels the community benefits and boasts of the achievement. Whatever is, therefore, affecting the Church in Africa should be affecting the Church all over. However, cultural differences seem to create barriers between groups of people.

\section{Summary}

As noted by Ford (1991:153), Christ's servant leadership provides an example of what it is to serve. Christ demonstrated to his disciples that whoever wants to be great should be servant of all, as Christ himself exemplified this by washing his disciples' feet. France (2002:418) argues that Christ teaches and practices humility and it was through self-emptying that he came to redeem the world (Phlp 2). Servant leadership begins with a passion for serving others, and so it is other-centred rather than being ego-centric. Sendjaya and Sarros (2002:60) argue that servant leadership embraces moral aspects that respect other people as befitting respect and honour.

Ubuntu leadership has the community needs at heart and upholds community values. From my point of view, ubuntu leadership philosophy is full of wisdom, only if practitioners are faithful to its principles. Kirk and Bolden (2006) argue that there is some 'tension between the power of the community (ubuntu) and the power of position' (p. 8). Similar tension from power centres may be experienced in contexts such as that of the Anglican Church where the church is episcopally led and synodically governed (CPCA 1980). The episcopate or bishop forms one centre of power, while the community, the people, forms a Synod which is the other centre of authority. In view of leadership challenges faced by many African countries, solutions seem to lie within the organisations choosing the leadership style they strongly identify with. Servant and ubuntu leadership models resemble each other and have the potential of being jointly applied in institutions to shape leadership ideas.

Both $u b u n t u$ and servant leadership are possible ways of looking at leadership differently and could bring better leadership skills if one chooses to implement these leadership views. In this conversation, the recent empirical research has revealed that neither $u b u n t u$ nor servant leadership ideas are in practice in the Anglican Diocese of Harare. The leadership exhibited by Kunonga in Harare is apparently autocracy and dictatorial.

\section{Conclusion}

In conclusion, the discussion has established that paying attention to ubuntu philosophy and servant leadership principles would contribute towards positive leadership practices in the Anglican Diocese of Harare. Swinton and Mowat (2006:9) argue that Christian leadership has a challenge to carry out its pastoral mission, critically and honestly reflecting on leadership as a theological issue, and merge church practices and experience of Christians with practices of the world culminating in goals that transcend boundaries of human experience and expectation executed in faithful practice.

\section{Acknowledgements Competing interests}

The authors declare that they have no financial or personal relationships which may have inappropriately influenced them in writing this article.

\section{Authors' contributions}

The article is based on J.M. PhD thesis with J.A.M. as supervisor.

\section{References}

Baggett, B., 1997, Power serve: 236 inspiring ideas on servant leadership, Saltillo Press, Germantown, TN.

Bishi, G., 2015, The colonial archive and contemporary chieftainship claims: The case of Zimbabwe, 1935 to 2014, University of Free State, Bloemfontein.

Block, P., 1993, Stewardship: Choosing service over self-interest, Berrett-Koehler, San Francisco, CA.

Block, P., 2011, 'Servant leadership: Creating an alternative future', in S.R. Ferch \& L.C. Spears (eds.), The spirit of servant leadership, pp. xiii-xxvi, Paulist Press, New York.

Broodryk, J., 2006, Ubuntu: Life coping skills from Africa, Knowledge Publishing, Randburg.

Chimuka, T.A., 2013, 'Chieftainship: A platform for traditional religion and political participation in Zimbabwe,' in E. Chitando (ed.), Prayers \& players: Religion and politics in Zimbabwe, pp. 63-81, Sapes Books, Harare.

Conger, G., 2010, 'Zimbabwe Supreme Court Upholds Dr. Kunonga as Bishop of Harare', viewed 04 October 2016, from https://geoconger.wordpress.com/2010/05/14/

Covey, S.R., 2006, 'Servant leadership: Use your voice to serve others', Leadership Service, 23(12), 5-6.

CPCA, 1975, Acts of the Diocese of Harare, Church of the Province of Central Africa, s.l., Harare.

CPCA, 1980, Constitution and canons: Church of the Province of Central Africa, s.l., Harare.

Ebegbulem, J.C., 2012, 'Corruption and leadership crisis in Africa: Nigeria in focus', International Journal of Business and Social Science 3(11), 221-227.

Ferch, S.R. \& Spears, L.C. (eds.), 2011, The spirit of servant leadership, Paulist Press, New York.

Ford, L., 1991, Transforming leadership: Jesus' way of creating vision, shaping values \& empowering change, Inter Varsity Press, Downer's Grove, IL.

France, R.T., 2002, The gospel of Mark, The Paternoster Press, Carlisle.

Greenleaf, R.K., 1970, The servant as a leader, The Robert K Greenleaf Center, Indianapolis, IN.

Greenleaf, R.K., 1996, On becoming a servant leader, Jossey Bass, San Francisco, CA.

Greenleaf, R.K. \& Spears, L.C., 1977, Servant leadership: A journey into the nature of legitimate power and greatness, Paulist Press, New York.

Greenleaf, R.K. \& Spears, L.C., 1998, The power of servant-leadership essays, BerrettKoehler Publishers, San Francisco, CA.

Gunda, M.R., 2008, 'The reign of Bishop Nolbert Kunonga: Nationalist spirit or empire builder?', Missionalia: Southern African Journal of Missiology 36(2/3), 299-318.

Hays, R., 1996, Moral vision of the New Testament: A contemporary introduction to New Testament ethics, Bloomsbury Academic, London.

Kirk, P. \& Bolden, R., 2006, African leadership: Insights, meanings, and connotations, Zanzibar, s.n.

Kouzes, J.M. \& Posner, B., 1995, The leadership challenge, Jossey-Bass, San Francisco, CA.

Louw, D.J., 2002, 'Ubuntu and the challenges of multiculturalism in post-apartheid South Africa', QUEST: An African Journal of Philosophy 15(1-2), 15-33.

Magesa, L., 2003, 'Theology of democracy', in J.N.K. Mugambi \& A. Nasimiyu-Wasike (eds.), Democracy and reconciliation: A challenge for African Christianity, pp. 117-134, Acton, Nairobi.

Mangaliso, M., 2001, 'Building competitive advantage from ubuntu: Management lessons from South Africa', Academy of Management Executive 15(3), 23-33. https://doi.org/10.5465/AME.2001.5229453 
Msila, V., 2008, 'Ubuntu and school leadership', Journal of Education 44, 67-84.

Musiyambiri, J., 2016, 'Leadership challenges to the episcopacy in the Anglican Diocese of Harare in post-independent Zimbabwe: A pastoral theological perspective', PhD thesis, Practical Theology, University of Pretoria.

Ndaba, W., 1994, Ubuntu in comparison to Western philosophies, Ubuntu School of Philosophy, Pretoria.

Nthamburi, Z., 2003, 'Theology and politics in Africa', in J.N.K. Mugambi \& A. Nasimiyu- Wasike (eds.), Democracy and reconciliation: A challenge for African Christianity, pp. 135-162, Acton, Nairobi.

Obiakor, F.E., 2004, 'Building patriotic African leadership through African-centered education', Journal of Black Studies 34, 402-422. https://doi.org/10.1177/ 0021934703258757

Ogot, B., 1963, 'From the Chief to president', Transition, No. 10, pp. 26-30, Indiana University Press, Bloomington, IN

Osmer, R.R., 2008, Practical theology: An introduction, Wm. B. Eerdmans Publishing Co., Grand Rapids, MI.

Prinsloo, E.D., 1998, 'Ubuntu culture and participatory management', in P.H. Coetzee \& A.P.J. Roux (eds.), The African philosophy reader, pp. 41-51, Routledge, London.

Prosser, S., 2007, To be a Servant-leader, Paulist Press, New York.

Russell, R.F., 2001, 'The role of values in servant leadership', Leadership and Organisational Journal 22(2), 76-83. https://doi.org/10.1108/014377301 10382631
Russell, R.F. \& Stone, A., 2002, 'A review of servant leadership attributes: Developing a practical model', Leadership \& Organization Development Journal 23(3), 145-157. https://doi.org/10.1108/01437730210424

Samkange, T.M., 1980, Hunhuism or ubuntuism: A Zimbabwe indigenous political philosophy, Graham Publishing, Salisbury.

Sendjaya, S. \& Sarros, J.C., 2002, 'Servant leadership: Its origin, development, and application in organisations', Journal of Leadership Organisation Studies 9(2) 57-64. https://doi.org/10.1177/107179190200900205

Sims, B.J., 1997, Servanthood: Leadership for the Third Millennium, Cowley, Cambridge, MA.

Smith, C., 2005, 'Servant leadership: The leadership theory of Robert K. Greenleaf', Info 640-mgmt., of info., Orgs, December 4, 1-17.

Spalthoff, U., 2013, 'The spirit of ubuntu and common good', Globalisation for the Common Good Initiative, Paris.

Spears, L.C., 1996, 'Reflections on Robert K. Greenleaf and servant-leadership', Leadership \& Organization Development Journal 17(7), 33-35. https://doi.org/ 10.1108/01437739610148367

Spears, L.C., (ed.), 1998, The power of servant-leadership: Essays by Robert K. Greenleaf, Berrett-Koehler Publishers, San Francisco, CA.

Swinton, J. \& Mowat, H., 2006, Practical theology and qualitative research, SCM Press, London.

Tutu, D.M. \& Allen, J., 2011, God is not a Christian: And other provocations, Harper One, New York.

Weinrich, A.K.H., 1971, Chiefs and Councils in Rhodesia; Transition from Patriarchal to Bureaucratic Power, Heinemann, London. 